\title{
Paideusis
}

\section{Sexual and Gender Diversity in Schools: An Introduction}

Donald Cochrane

Volume 22, Number 1, 2014

Sexual and Gender Diversity in Schools

URI: https://id.erudit.org/iderudit/1071460ar

DOI: https://doi.org/10.7202/1071460ar

See table of contents

Publisher(s)

Canadian Philosophy of Education Society

ISSN

0838-4517 (print)

1916-0348 (digital)

Explore this journal

Cite this document

Cochrane, D. (2014). Sexual and Gender Diversity in Schools: An Introduction. Paideusis, 22(1), 3-8. https://doi.org/10.7202/1071460ar

(c) Donald Cochrane, 2014

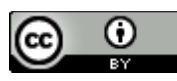

This document is protected by copyright law. Use of the services of Erudit (including reproduction) is subject to its terms and conditions, which can be viewed online.

https://apropos.erudit.org/en/users/policy-on-use/
This article is disseminated and preserved by Érudit.

Érudit is a non-profit inter-university consortium of the Université de Montréal, Université Laval, and the Université du Québec à Montréal. Its mission is to promote and disseminate research.

https://www.erudit.org/en/ 


\title{
Sexual and Gender Diversity in Schools: An Introduction
}

\author{
DONALD COCHRANE \\ University of Saskatchewan
}

In Canada in the mid-sixties, homosexuality was deemed illegal by the courts, ${ }^{1}$ sinful by religious institutions, ${ }^{2}$ and a sign of illness by the mental-health establishment. ${ }^{3} \mathrm{~A}$ battle against these indictments has raged relentlessly over the past fifty years. Reform began in 1967 when then Justice Minister Pierre Trudeau famously proclaimed that "...there's no place for the state in the bedrooms of the nation.....what's done in private between adults doesn't concern the Criminal Code." 4 His proposed amendments to the Criminal Code were passed in 1969. All provinces now specify "sexual orientation" as a prohibited ground for discrimination. ${ }^{5}$ Many Christian churches have retreated from fundamentalist positions, ${ }^{6}$ and millions of

\footnotetext{
${ }^{1}$ In 1965, Everett Klippert acknowledged to police that he was gay, had had sex with men over a 24-year period, and was unlikely to change. A psychiatrist testified that Klippert was "an incorrigible homosexual." In 1967, he was sent to prison indefinitely as a "dangerous sex offender," a sentence that was upheld by the Supreme Court of Canada that same year. He was the last person in Canada to be arrested, charged, prosecuted, convicted, and imprisoned for homosexuality.

2 The most definitive statements of this position can be found in missives produced by the Vatican which have not been substantially revised over the last forty years. These documents constrain Catholic school boards in Canada when faced by activist students and impatient provincial legislatures. For example, in order to defend itself from impending legislation, the Ontario Catholic School Trustees' Association produced a document entitled "Respecting Difference" (2012) which refers to the Catechism of the Catholic Church (1997) as the "primary teaching document of the Church." The "Catechism" is a guide on how to see the world and "to live as a good Catholic." Homosexual acts are described as "intrinsically disordered," "contrary to the natural law," "do not proceed from a genuine affective and sexual complementarity," and "under no circumstances can they be approved." This passage draws on Persona Humana (1975) and reiterates the view that homosexual acts are a "serious depravity" and "intrinsically disordered." To clarify some issues pertaining to pastoral care, the Vatican issued a letter in 1986 which repeated the line taken in Persona Humana: the inclination of a homosexual person "must be seen as an objective disorder"; "living out of this orientation in homosexual activity is [not a] morally acceptable option"; and an "authentic pastoral programme" must state clearly "that homosexual activity is immoral."

3 Beginning in 1952, the American Psychiatric Association's Diagnostic and Statistical Manual of Mental Disorders (DSM-I) classified homosexuality as a mental illness. Before then, psychiatrists and psychologists looked at homosexuality as a perversion and a deviant behaviour, but the idea that it was a mental illness was considerably more controversial.

${ }_{4}$ Trudeau made these remarks in defence of the omnibus bill to reform the Criminal Code (Criminal Law Amendment Act, 1968-69, S.C. 1968-69, c. 38).

${ }^{5}$ In 1977, Quebec included sexual orientation in its human rights code making it the first province in Canada-in fact, the first jurisdiction in the world larger than a city or county - to pass such a civil rights law. Other provinces followed suit, some reluctantly (Ontario, 1986; Manitoba, 1987; Yukon, 1987; Nova Scotia, 1991; New Brunswick and British Columbia, 1992; Saskatchewan, 1993; Newfoundland, 1995; Prince Edward Island and Alberta, 1998; Nunavut, 1999; and the Northwest Territories, 2002).
}

(C) Copyright 2014. The authors, Donald Cochrane, assigns to Paideusis the right of first publication and educational and non-profit institutions a non-exclusive license to use this document for personal use and in courses of instruction provided that the article is used in full and this copyright statement is reproduced. Any other usage is probibited without the express permission of the author. 
North Americans were "cured" of their mental illness when, in 1973, the American Psychiatric Association removed homosexuality from the list of mental disorders in its Diagnostic and Statistical Manual.7

Simply reviewing a list of landmark legal decisions, votes in federal and provincial assemblies, resolutions accepted by teachers' federations, decisions to remove homosexuality from the category of a mental illness, resolutions passed by religious assemblies grossly oversimplifies the complexity, effort, struggle, and pace of major social change. Court battles were fought fiercely particularly over a fifteen year period beginning in the early 1990s. ${ }^{8}$ Debates at teachers' conventions were heated and vituperative. ${ }^{9}$ Interand intra-party struggles to add sexual orientation to provincial human rights codes were often acrimonious and divisive (Rayside, 1988). The process to remove homosexuality from the list of mental illnesses in the Diagnostic and Statistical Manual was controversial and turbulent (Bayer, 1981). Major social change is slow as students of the Suffragette Movement in Canada will know.

Though these significant and influential events have been widely publicized, many officialsparticularly in education-have resisted change. This is particularly true where religion and education have crossed paths (see Bialystok; Bouley, Yeung, Lieung, and Burns; Callaghan; and McDonough in this issue). Even the language used to describe, report, and interpret events is contentious. For example, Mizzi and Walton offer a subtle analysis of "sexual minority" pointing out that it functions as an umbrella term that "serves the purposes of religious fundamentalist and political groups that demonize minority sexualities to the exclusion of identity, background, or family status." 10

Students continue to be harassed and teachers remain closeted. The introduction of GSAs in both public and separate schools can be difficult and even prohibited despite evidence that they are a "best practice." Teachers and school counsellors have been asked to remove "safe-space" posters from their doors and notice boards. Same-sex students are prohibited from "tactile freedoms" that are granted routinely to "hetero" couples. Though the Hall v. Durbam Catholic School Board decision was rendered twelve years ago, not many gay or lesbian couples attend their graduation prom together. The literature curriculum is typically bereft of references to gay, lesbian, or transgender authors and characters in plays, novels, and poetry. In

${ }^{6}$ Quakers and Unitarians have traditionally supported the rights of gays and lesbians. The United Church of Canada was the first of the mainstream Protestant churches in Canada to espouse inclusivity. Since 1988, the Church has formally held that homosexuality "is not in itself a barrier" to becoming a minister. At its 37th General Council in 2003, it affirmed that, far from being a sin, "human sexual orientations, whether heterosexual or homosexual, are a gift from God and part of the marvelous diversity of creation." In 2012, the church elected the Rev. Gary Paterson as its Moderator. Paterson is an openly gay man married to the Rev. Tim Stevenson, the first openly gay man to be ordained as one of its ministers. In July, 2011, the Church-wide Assembly of the Evangelical Lutheran Church in Canada passed a new sexuality statement permitting clergy to commit to same-gender partnerships and allowing the blessing of same-sex unions. Since the 1970s, the Anglican Church has wrestled with controversy regarding homosexuality and established national and local policies toward greater dignity, inclusion, and fair treatment for all members at all levels. In 2002, the Diocese of New Westminster endorsed the blessing of same sex unions. Since then, 11 of the church's 29 dioceses have endorsed such blessings. The General Synod in 2013 decided to receive a resolution for discussion at its next meeting in 2016 "to allow the marriage of same-sex couples in the same way as opposite sex couples." Presbyterians, Baptists, and Evangelicals in Canada remain committed to strict fundamentalist interpretations of Scripture and so, among other things, do not approve of same-sex marriage. The Roman Catholic Church has resisted change, though the release of Instrumentum Laboris-The Pastoral Challenges of the Family in the Context of Evangelization in preparation for the Synod on the Family to be held in Rome in the fall of 2014 under Pope Francis may signal a change. Accessed on July 20, 2014, at http://www.vatican.va/roman_curia/synod/documents/rc_synod_doc_20140626_instrumentum-laboris

familia_en.html.

${ }^{7}$ The American Psychological Association endorsed the change two years later. The Canadian Psychological Association followed suit in 1982.

8 See Haig v. Canada (1992), Canada (Attorney General) v. Mossop (1993), Layland v. Ontario (Minister of Consumer and Commercial Relations) (1993), Egan v. Canada (1995), Canada (Attorney General) v. Moore (1998), Vriend v. Alberta (1998), Rosenberg v. Canada (Attorney General) (1998), and M. v. H. (1999). See also Chamberlain v. Surrey School District No. 36 (2002) and the numerous cases in provincial courts across Canada over same-sex marriage.

${ }^{9}$ In 1997, the British Columbia Teachers' Federation (BCTF) became the first teacher union Canada to pass a resolution calling on its members to combat homophobia.

${ }^{10}$ So persuaded were we by Mizzi and Walton's argument that we revised the original title of this special issue. 
social studies, LGBTQ persons and events-both historical and contemporary-are seldom, if ever, recognized and highlighted. ${ }^{11}$

Public school officials often rely on conventional norms about what is "correct" behaviour. For example, two girls or two boys who hold hands as they walk down a hallway are reprimanded for acting "inappropriately," though what is inappropriate is not—and perhaps cannot be-substantiated. Straight and gay students alike are initiated into a world that is stripped of diversity and, so, presented with a distortion of social and cultural reality.

In public school systems, pockets of power work to maintain conventional views-superintendents are beholden to school boards, principals to superintendents, teachers to principals. The price can be high for those who challenge the power structure. Resistance to change is much more centralized in separate school systems. Catholic school policy is grounded on explicit Vatican positions, developed pastoral guidelines commissioned and approved by bishops, and implemented through workshops that are overseen by local church officials. It has an orderliness to it that some in the public system might envy. How policy is enforced on principals, teachers, and students is illuminated by Callaghan's application of the Panopticon, a mode of widespread surveillance: school employees never know when they are being watched and, so, to be prudent must act as though they are always being observed.

The Catholic system's deep commitment to the use of reason dates back to Thomas Aquinas and runs strongly through the Jesuit tradition. Catholics explain their doctrinal position at length in documents that range from Vatican encyclicals and letters to bishops, to provincial pastoral guidelines, to school superintendents' letters to parents. But with each public statement, they invite a rejoinder. As Callaghan notes, this process opens up a public discussion which it cannot control. Catholic officials are obliged to "speak verbosely" about that which they would have preferred to remain silent.

One such document was published by the Ontario Catholic School Trustees' Association (OCSTA) in anticipation of provincial anti-bullying legislation that was likely to be gay-sympathetic (OCSTA, 2012). Bialystok argues that the concept of respect employed by the OCSTA is completely inadequate for the task. Indeed, without the necessary element of "recognition," the "respect" in the document is not moral respect at all. In any case, given the system's refusal to undertake any empirical research to discover the extent to which it has a problem with homophobia in its schools and its refusal to accept "best practices" (GSAs), Bialystok is skeptical about its commitment to combat homophobia.

While Bialystok confines herself to what she perceives to be a fatal ethical inadequacy of an OCSTA document, McDonough turns his attention to a damaging theological inconsistency in Catholic doctrine. He critiques the narrow traditional conception of "scandal" and replaces it with a broader one. He concludes that the real scandal in its church schools is the marginalization of lesbian, gay, bisexual, transgender, queer, and questioning youth. McDonough reflects on the life of Jesus, who challenged the prevailing laws and cultural norms of his time. Jesus "associated with sinners, confronted the Sabbath laws, and disrupted the Jerusalem temple, driving out the money-changers and vendors." McDonough compares the behaviour of those in the Church who seek to protect codified and institutionalized norms to that of the Pharisees. A strict adherence to religious codes is an external test of one's holiness, not an inward test of one's faith. McDonough wonders on what grounds Jesus's scandalous disruptions differ from LGBTQ students requesting GSAs in their Catholic schools.

McDonough notes that Catholic schools currently provide special programs for pregnant and parenting students. He asks why Catholic schools do not attempt to hide and silence these persons as well. He asks whether the offer of these programs implies the school's tacit approval of heterosexual relationships outside the context of marriage, which is also contrary to Church teaching on chastity. He concludes that this disparity reflects a political concern of the hierarchy who view LGBTQ organizations as a threat to their teaching and governing authority, while it perceives unchaste heterosexuals as simply persons in need of charitable attention.

Herriot demonstrates that GSAs most often start as self-help groups but can move to become centres of political activism, both in their schools and in the community at large. As students gain a sense of the validity of their own identity (indeed, pride in who they are), they recognize that they can and should struggle

11 On the importance of models to promote diversity, see Boulay et al. 
against those people, authorities, and doctrines that have shamed and oppressed them; they are less and less interested in the kind of "pastoral care" being recommended by Catholic authorities. Thus, GSAs make an important contribution to civic education. This evolving feature of GSAs may well explain why some school officials may not have welcomed them in their schools. ${ }^{12}$

The significant policy changes wrought by Ontario's Bill 13 and Manitoba's Bill 18 are remarkable in that they were sparked by high-school student activism. The combustible ingredients in Ontario were courageous and articulate students, an obstinate school board, ${ }^{13}$ and a sympathetic and dogged media. ${ }^{14}$ All three ingredients were present in May, 2011, when Leanne Iskander, a high-school student at St. Joseph's Catholic Secondary School in Mississauga, requested permission to start a GSA. The board turned down her request and a struggle for public opinion erupted.

The role students played in strengthening the language of Bill 13 in Ontario was significant. In early versions of the legislation, the language was so vague that a school board could overrule students were they to choose to call their groups "GSAs." Speculation was rife that the government feared a court challenge by Catholic school trustees. What is most interesting about the political process at this point was that Education Minister Laurel Broten's views were changed (or her resolve was strengthened) after a moving plea was made by a delegation of high-school students. On May 25, 2012, she announced that the government would tighten the language in the Accepting Schools Act to ensure Catholic school boards could not refuse students who wanted to form a support group and call it a GSA (Houston, 2012).

In its final version, the bill required every board to "support pupils who want to establish and lead activities or organizations that promote the awareness and understanding of, and respect for, people of all sexual orientations and gender identities, including organizations with the name gay-straight alliance" (Bill 13, 303.1 [1]). To eliminate any equivocation, the government added a clause to ensure that its intentions were clear: "For greater certainty, neither the board nor the principal shall refuse to allow a pupil to use the name gay-straight alliance or a similar name for an organization" (Bill 13, 303.1 [2]). That is, if a student in a Catholic school in Ontario wanted to start a GSA and call it a GSA, no principal, board, or bishop could stand in the way. Clearly, the battle lines between church and state had been drawn. On June 5, 2012, Ontario's anti-bullying bill, known as the Accepting Schools Act, passed third reading. ${ }^{15}$

Events unfolded in Manitoba in 2013 somewhat differently from what had transpired in Ontario. ${ }^{16}$ The left-leaning NDP government introduced Bill 18, A Safe and Inclusive Schools Amendment to the Public School Act.

\footnotetext{
12 The Evangelical Fellowship of Canada recognized this dimension of GSAs in their brief that opposed Manitoba's Bill 18: "Gay-Straight Alliances have an inherently political nature to them. As has been pointed out in the media,...[the] amendment does not discuss a 'gay-straight dialogue group,' or a 'gay-straight mutual education society,' but a 'gaystraight alliance'. There are conceptual and inherent differences between these three types of student associations. Alliances are formed in order to press political agendas...." Quoted from "Falling Short: Manitoba's Bill 18, the Safe and Inclusive Schools Act” released by The Evangelical Fellowship of Canada, (May) 2013, p. 15. Accessed on July 17, 2014, at http:/ / files.efc-canada.net/si/Education/Falling\%20Short,\%20Bill\%2018.pdf.

13 In one case, when defending the decision in November, 2010, to ban GSAs, the chair of the Halton Catholic District School Board, Alice Anne Lemay, was quoted in Xtra on January 5, 2011, as saying, "We don't have Nazi groups either. Gay-Straight Alliances are banned because they are not within the teaching of the Catholic Church."

${ }^{14}$ In this case, the excellent reporting of Kate Hammer of the Globe and Mail and Andrea Houston of Xtra.

15 The final vote was 65-36. All of the negative votes were cast by Progressive Conservative members.

16 The initiatives in Ontario and Manitoba were both successful, if protracted, because they were brought forward by a governing party with large majorities. A private members' non-binding resolution (Motion 503) in Alberta, introduced by Liberal MLA Kent Hehr, read:
}

Be it resolved that the Legislative Assembly urge the Government to introduce legislation, like Manitoba's and Ontario's, requiring all school boards to develop policies to support students who want to lead and establish gay-straight alliance activities and organizations, using any name that is consistent with the promotion of a positive school environment that is inclusive, welcoming, and respectful for all students regardless of sexuality, sexual orientation, or gender identity. 
In an "Explanatory Note," the bill made clear that it encompassed "student activity that promotes the school environment as being inclusive of all pupils, including student activities and organizations that use the name 'gay-straight alliance'." Though the impetus for the bill did not come from students, student involvement was significant. About the time the bill was being introduced into the Legislative Assembly, 17-year-old Evan Wiens was trying to start a GSA in his public school in Steinbach. His principal permitted him to start the group, but not to advertise in the school because, he was told, that would infringe on religious freedoms (Short, 2013, 2014a, \& 2014b). Wiens argued that a double standard was being set that allowed local churches to hold morning prayers in his school. After some unflattering media coverage, the school district overruled the principal, and Evan was permitted to advertise his club just as others were allowed to do. The furor that ensued over the bill led to passionate public meetings. ${ }^{17}$ More than 300 people registered to speak to the bill over a ten-day period, including Evan, whose protest had attracted significant media coverage. On September 13, 2013, the amendment act passed third reading. ${ }^{18}$ Then, on July 22, 2014, New Brunswick became the third province in Canada to permit a student or a teacher to start a GSA and call it a GSA (for details see "Government formally backs schools gay/straight alliances", 2014).

Though Tanchuk supports the right of students to form GSAs in their schools, he puzzles over the ultimate ethical basis for his own view. He examines Kymlicka's view that might justify this right and concludes that it fails. While this does not entail that those opposed are any more justified in their position, he and they are left in a quandary. Ever the optimist, he thinks that, with more work, it should be possible to "establish the most coherent theory of the moral landscape." At that point, we may be able to justify measures such as Bill 13 (Ontario) and Bill 18 (Manitoba) against religious dissent.

As Tomkins (1986) demonstrated nearly thirty years ago, public-school curriculum in Canada has always been hotly contested terrain. The most celebrated legal case in Canada involving gay issues and a school board-Chamberlain v. Surrey School District—was taken all the way to the Supreme Court. ${ }^{19}$ Matrim notes that the Toronto District School Board—the largest board in the country-has developed an equity policy which commits the board to developing an anti-heterosexist and anti-homophobic curriculum. Part of this curriculum explored cross-dressing, and this became a hot political issue in the 2011 provincial election. He argues that students in most classes lack any freedom to challenge the prevailing "moral logic of heterosexism," and this "robs all students of their autonomy and freedom in some way."

Parents also play various roles in challenging schools regarding what students will be exposed to. Boulay et al. remind us that the Alberta government amended its human rights legislation in 2009 to allow parents to remove their children from classes which explicitly discuss religion, sexuality, and sexual orientation ("Alberta passes law", 2009). They propose that all students be exposed to LGBTQ role models-both in-person and through school curriculum resources. We do not shy away from this strategy for sexism and racism. It is time, they argue, to expand this initiative to LGBTQ issues for the same sorts of reasons.

However, some parents want to take the issue of inclusion one step further. They are actively challenging schools to "let them in" and not just on the issue of classroom materials. Keener's research explores the "in/visibility" of non-heterosexual parents whose children attend schools where the heterocentric culture is deeply entrenched. These same-sex parents also want to be involved in school activities; they want to be visible both to students and other parents; and they want to be role models in just the way that Boulay et al. propose. Their trials are captured in painful interview extracts.

Voting for the resolution on April 7, 2014, were 12 Progressive Conservatives, 3 members of the NDP, and 4 Liberals; voting against were 22 Progressive Conservatives and 9 members of the Wild Rose Party ("Alberta legislature votes down", 2014).

17 About 1200 people attended one protest meeting in Steinbach, a small city with a strong Mennonite population, to express their opposition to the proposed legislation. Curiously, the Roman Catholic establishment was largely inactive and silent (Burwell, 2014, pp. 7-9).

18 The final vote was 36-16. All of the negative votes were cast by Progressive Conservative members.

${ }^{19}$ Chamberlain v. Surrey School District No. 36, [2002] 4 S.C.R. 710, 2002 SCC 86. The issue was whether James Chamberlain would be allowed to introduce his Kindergarten and Grade One classes to three children's books: Asha's Mums, Belinda's Bouquet, and One Dad, Two Dads, Brown Dad, Blue Dads. It is reported that the legal fees cost Surrey taxpayers over $\$ 1,200,000$. 
The battles are being fought on so many fronts. A revolution is underway and philosophers have a role to play.

\section{References}

Alberta legislature votes down Gay-Straight Alliance bill. (2014, April 08). Retrieved from http://globalnews.ca/news/1258107/alberta-legislature-votes-down-gay-straight-alliance-bill/

Alberta passes law allowing parents to pull kids out of class. (2014, June 02). Retrieved from http://www.cbc.ca/news/canada/alberta-passes-law-allowing-parents-to-pull-kids-out-of-class1.777604

Bayer, R. (1981). Homosexuality and American psychiatry: The politics of diagnosis. New York: Basic Books.

Burwell, J. S. (2014, June). Pope Francis and Bill 18. Paper presented at the CCEAM CASEA Conference, Fredericton, New Brunswick. Retrieved from https://classic.regonline.com/AttendeeDocuments /1534405/68869575/PopeFrancisandBILL18Burwell_69025.pdf

Bill 13: Accepting Schools Act. (2012). Retrieved from the Legislative Assembly of Ontario website: http://ontla.on.ca/web/bills/bills_detail.do?locale $=$ en\&BillID $=2549$

Government formally backs schools gay-straight alliances. (2014, June 22). Retrieved from http://www.cbc.ca/news/canada/new-brunswick/government-formally-backs-school-gay-straightalliances-1.2714771

Houston, A. (2012). Ontario tightens Bill 13 so school boards can't reject GSAs. Retrieved from http://blog.apastyle.org/apastyle/2010/11/how-to-cite-something-you-found-on-a-website-in-apastyle.html

Rayside, D. (1988). Gay rights and family values: The passage of Bill 7 in Ontario. Studies in Political Economy, 26, 109-47.

Ontario Catholic School Trustees' Association (OCSTA). (2012). Respecting difference: A resource for Catholic schools in the province of Ontario regarding the establishment and running of activities and organizations promoting equity and respect for all students. Retrieved from https://www.tcdsb.org/Board/EIE/Documents/Jan25\%20Final-RespectingDifference.pdf.

Short, D (2013). Bill 18's infringements on religious belief are 'reasonable' Retrieved from http://www.winnipegfreepress.com/opinion/analysis/bill-18s-infringements-on-religious-belief-arereasonable-198912371.html

Short, D (2014a). Bound for glory: Bill 18, The Public Schools Amendment Act (Safe and Inclusive Schools). Manitoba Law Journal, 36(2), 125-47.

Short, D. (2014b). Queering schools, GSAs, and the law. In G. Walton (Ed.), The gay agenda: Claiming space, identity \& justice (327-343). New York: Peter Lang.

Tomkins, G. S. (1986). A common countenance: Stability and change in the Canadian curriculum. Scarborough, ON: Prentice-Hall Canada.

\section{About the Author}

Donald Cochrane is Professor Emeritus at the University of Saskatchewan. His research interests have centred on the intersection of ethics and education. His fourth-year elective course "Gay and Lesbian Issues in Education", taught initially in 1998, was the first course approved at his university to be devoted exclusively to issues of sexual and gender diversity. For seventeen years, he has been the chief organizer of the university's "Breaking the Silence: Facing Issues of Sexual Orientation and Gender Identity" conference. He has co-edited four books in philosophy of education and co-authored Ethics in School Counseling (1995). 